\title{
EDITORIAL
}

\section{Transnational Dimensions of Climate Governance}

\section{CLIMATE CHANGE AS AN ARENA OF TRANSNATIONAL ENVIRONMENTAL LAW}

It is fitting that the second issue of Transnational Environmental Law (TEL) focuses on governance and climate change. Transnational environmental law views governance as an outgrowth of local, regional and transboundary communications and pressures. The challenges of transnational governance - and its necessity - are especially clear in the context of climate change. On the one hand, climate change is a global phenomenon with globally distributed causes, thus requiring a global response. On the other hand, emissions always take place from specific locations within particular jurisdictions, and the impacts of climate change will vary from place to place, requiring diverse adaptation measures. Thus, it is inherent in the nature of climate change that responses will be multi-scalar and multi-jurisdictional, raising profound issues of governance. Moreover, because of the ubiquity of climate and of the activities causing emissions, climate governance modifies rules that govern private control over resources - in other words, with the property system.

The articles in this issue examine a broad range of issues relating to governance, but they can be divided into two general themes. The first theme relates to the internal structure of climate governance. Responses to climate change involve a complex interplay between different geographic jurisdictions (horizontal governance issues) and interplay between different tiers of governance (vertical governance issues). At times, vertical and horizontal linkages collide - for example, when disputes between contesting geographic authorities are referred to a higher-level authority, resulting in a vertical resolution of a horizontal dispute in what could be called a 'triangular' relationship. Considering the whole structure of sometimes synergistic and sometimes competing authorities, we perceive the emerging contours of an expanding and still evolving network of governance.

The second theme in the issue is the interplay between public and private modes of resource control - or between governance and property. Climate governance may restrict property use in some ways, while creating new forms of property in others. For instance, emissions allowances may be considered a new form of property. However, the entitlements are constrained and limited in some ways that we traditionally do not associate with the concept of property. Meanwhile, sea level rise as a result of climate change 
threatens coastal areas. Does this impact upon property rights in the affected areas? As we will see, these are questions with which scholars and legal systems are still struggling.

\section{THE INTERNAL STRUCTURE OF CLIMATE GOVERNANCE}

Since climate change is a global problem, one might expect that the keystone of climate policy would be a binding global agreement to control emissions. Global cooperation in some form is undoubtedly required. ${ }^{1}$ But negotiating a global agreement has proved to be no easy matter, some halting steps forward notwithstanding. Pending effective global agreement, climate mitigation is dispersed over an almost bewildering number of lower levels of governance.

Even within a single jurisdiction, mitigation efforts can take place at various levels of government. In the United States (US), for instance, state governments have actively engaged with the issue of climate change. ${ }^{2}$ By 2006 , every state had taken certain steps to address climate change, ${ }^{3}$ such as the adoption of renewable portfolio standards (RPSs), which require that a percentage of retail electricity sales be derived from renewable sources. ${ }^{4}$ Exemplifying its leadership on climate issues, California's RPS has an especially ambitious 33 per cent target by $2020 .^{5}$

California also mandated the very first inventory of in-state greenhouse gas emissions in $1998 .{ }^{6}$ Eight years later, Governor Schwarzenegger signed the California Global Warming Solutions Act of 2006 (AB 32), ${ }^{7}$ which requires California to reduce emissions to the 1990 level by $2020 .^{8}$ The significance of transnational communication is illustrated by a statement by former British Prime Minister Tony Blair that its signing represented a 'historic day for the rest of the world as well'. 9 Blair and Schwarzenegger also entered into an agreement to share best practices on market-based systems and to cooperate to investigate new technologies; similar agreements now exist between California and states

1 See, e.g., K.H. Engel \& S.R. Saleska, 'The Case of Climate Change' (2005) 32 Ecology Law Quarterly, pp. $183-233$, at 187.

2 State efforts are described in E. Stein, 'Regional Initiatives to Reduce Greenhouse Gas Emissions', in M.B. Gerrard, Global Climate Change and U.S. Law (American Bar Association, 2007), pp. 315-42; D. Hodas, 'State Initiatives', in Gerrard, ibid., pp. 343-70. A survey of state efforts can be found in Pace Law School Center for Environmental Legal Studies, 'The State Response to Climate Change: 50-State Survey', in Gerrard, ibid., pp. 371-420.

3 Hodas, ibid., at p. 343; E.C. Schlanger, K.H. Engel \& S. Rider, Navigating Climate Change Policy: The Opportunities of Federalism (University of Arizona Press, 2011) provides a collection of thoughtful evaluations of this trend.

4 M.B. Gerrard, 'Introduction', in Gerrard, n. 2 above, pp. 1-27, at 22.

5 California Air Resources Board (CARB), 'RPS Program Overview', available at: http://www.cpuc.ca. gov/PUC/energy/Renewables/overview.

6 AB 4420 (Sher), Chapter 1506, Statutes of 1988.

7 AB 32 (Nunez), Chapter 488, California Statutes of 2006, codified at Cal. Health \& Safety Code $\S 38500$ et seq.

8 E. Chemerinsky et al., 'California, Climate Change, and the Constitution' (2007) 37 Environmental Law Reporter, pp. 10053-67, at 10053.

9 Ibid., at p. 10054. 
and provinces in Australia and Canada. ${ }^{10}$ Interestingly, Australian states were also in the forefront in addressing climate change prior to national action. ${ }^{11}$

The European Union (EU) has been a particularly energetic sub-global actor. The EU began operating the world's first mandatory carbon dioxide $\left(\mathrm{CO}_{2}\right)$ emissions trading scheme in January $2005,{ }^{12}$ and has since continued to develop an extensive package of climate change mitigation measures. ${ }^{13}$

Developing countries, too, are beginning to take action. China's $12^{\text {th }}$ five-year plan, which covers 2011-2015, now includes a 17 per cent reduction in energy intensity and a 10 per cent increase in the share of energy produced by renewables and nuclear. ${ }^{14}$ The plan establishes a longer-term goal of establishing a carbon trading market. ${ }^{15}$ China has also announced that it is 'willing to bear the obligations of a legally binding commitment', provided such a commitment is 'matched with China's economic development and capabilities based on the principles of common but differentiated responsibilities, fairness and environmental integrity'. ${ }^{16}$

In sum, climate change is an international problem, but it is not - or certainly not exclusively - tackled in the conventional way of unitary national actors cooperating through formal treaties. The sprawling range of national, regional and sub-national climate change efforts, requiring the involvement of an unprecedentedly large array of governmental authorities, defies traditional notions of international cooperation and cries out for theoretical clarification.

In their article on multi-level governance, Jacqueline Peel, Lee Godden and Rodney Keenan provide a framework for understanding this new form of network governance. They analyze case studies that include emissions trading systems, the REDD mechanism (Reducing Emissions from Deforestation and Forest Degradation in Developing Countries), climate litigation, adaptation and decentralization within federal systems. ${ }^{17}$ Peel, Godden and Keenan see weaknesses in relying on either a top-down or bottom-up approach. Instead, they advocate a multi-level governance approach, based on a recognition that 'trends toward fragmentation, decentralization and grassroots empowerment are producing a more "kaleidoscopic" world consisting of a "multi-layered system" of activity undertaken by states, international institutions, the private sector and non-governmental organizations'. ${ }^{18}$

10 Ibid., at p. 10059.

11 J. Peel, L. Godden \& R. Keenan, 'Climate Change Law in an Era of Multi-Level Governance' (2012) 1(2) Transnational Environmental Law, pp. 245-80, at 277.

12 See European Commission, Emissions Trading System (EU ETS) website at: http://ec.europa.eu/clima/ policies/ets/index_en.htm.

13 K. Kulovesi, E. Morgera \& M. Muñoz, 'Environmental Integration and Multi-Faceted International Dimensions of EU Law: Unpacking the EU's 2009 Climate and Energy Package' (2011) 48(3) Common Market Law Review, pp. 829-91, at 830.

14 J. Lewis, Energy and Climate Goals of China's $12^{\text {th }}$ Five-Year Plan (Pew Center on Global Climate Change, 2011), available at: http://www.c2es.org/docUploads/energy-climate-goals-china-twelfth-five-year-plan.pdf.

15 Ibid., p. 2.

16 'China Sets Conditions on Binding Climate Change Commitment after 2020', Xinhua English News, 6 Dec. 2011, available at: http://news.xinhuanet.com/english/china/2011-12/06/c_131290906.htm.

17 Peel et al., n. 11 above.

18 Ibid., at p. 251. 
The fragmentation and lack of universality of these mechanisms invite friction between jurisdictions. A contribution by Luca Rubini and Ingrid Jegou ${ }^{19}$ considers some of the 'triangular' issues raised by climate mitigation, where conflicting horizontal authorities may seek resolution from a higher-level institution. Their article analyzes whether World Trade Organization (WTO) law requires that emissions allowances be auctioned rather than distributed without charge. Advocates of free distribution of emissions allowances often invoke a combination of feasibility- and fairness-based arguments, claiming that the sudden imposition of a substantial extra cost on industry would be economically disruptive, and that it would excessively penalize firms for the side-effects of socially highly beneficial production. But these arguments are not without controversy. Others argue, along with Rubini and Jegou, that allowances should be auctioned. ${ }^{20}$ Their article defends the position that large-scale free distribution is unsound from an economic perspective, and questionable from a legal perspective, since it might be seen to constitute an unlawful subsidy under the WTO. Any provisions introduced into international trade law to exempt the free distribution of allowances from the application of the law on subsidies, they argue, should be narrowly construed and temporary.

The WTO will also need to address efforts to expand the scope of trading systems to include transportation or imported goods. The EU has brought international flights within its trading system, requiring allowances or offsets for all emissions during a flight (both inside and outside European air space). ${ }^{21}$ The EU has indicated that it would back down if an international agreement on airline emissions were in store. ${ }^{22}$ In the meantime, however, there is a serious question mark over the compatibility of the EU's actions with international trade law, and international law generally.

In her contribution to this issue, ${ }^{23}$ An Hertogen argues that the EU action should be considered lawful. The objection to the EU action is that it extends EU jurisdiction beyond its borders by regulating emissions from the airlines of other nations that take place outside EU airspace. Hertogen argues, however, that a contemporary understanding of sovereignty should take into account the right to prevent harms from occurring within the state in question, even if the harms are caused by actions elsewhere. To gauge the lawfulness of its unilateral action, the harm to the EU from emissions must be balanced against the intrusion on the sovereignty of other states as a result of the EU regulation. Hertogen argues that, in this instance, the scales point in favour of the EU, all

19 L. Rubini \& I. Jegou, 'Who'll Stop the Rain? Allocating Emissions Allowances for Free: Environmental Policy, Economics, and WTO Subsidy Law' (2012) 1(2) Transnational Environmental Law, pp. 325-54.

20 See D. Farber, 'Pollution Markets and Social Equity: Analyzing the Fairness of Cap and Trade' (2012) 39 Ecology Law Quarterly, pp. 19-26.

21 See J. Meltzer, 'Climate Change and Trade: The EU Aviation Directive and the WTO' (2012) 15(1) Journal of International Economic Law, pp. 111-56 (questioning whether the Directive complies with WTO requirements).

22 See D. Pruzin, 'Official says EU will not Suspend Inclusion of Airlines in Trading Plan as Talks Continue', Environmental Reporter, 3 Mar. 2012, p. 742, available at: http://news.bna.com/erln.

23 A. Hertogen, 'Sovereignty as Decisional Independence over Domestic Affairs: The Dispute over Aviation in the EU Emissions Trading System' (2010) 1(2) Transnational Environmental Law, pp. 281-301. 
the more so since allowing the EU to act unilaterally in this context can help to solve the collective action problem of entering into a global agreement on aviation emissions.

The discussion so far has focused on climate governance in connection with mitigation, but adaptation also raises significant governance challenges. We are witnessing increased efforts to develop roadmaps for responding to adaptation governance challenges in both the developed and developing world. ${ }^{24}$ But, apart from recognizing the growing urgency of adaptation actions and the inherently transnational nature of the challenge, the legal literature has not yet clarified how to fill the governance gaps. ${ }^{25}$

Adaptation issues arise in many contexts, but perhaps most clearly and predictably in coastal areas. Sea level rise is one of the most predictable effects of climate change. ${ }^{26}$ This will result in loss of coastal lands, ${ }^{27}$ inundation of some estuary systems with salt water, salt water intrusions into some drinking sources, and increased exposure to flood damage. $^{28}$

Coastal areas around the world will be faced with the need to adapt to these changes. In their contribution to this issue, Jonathan Verschuuren and Jan McDonald investigate the legal frameworks for coastal adaptation in developed countries. ${ }^{29}$ Adaptation is a multifaceted enterprise, as demonstrated by the article's analysis of international, EU and domestic regimes. Although the EU addresses adaptation in the contexts of river basin planning and coastal zone management, Verschuuren and McDonald's case studies of the Netherlands and the United Kingdom (UK) demonstrate that, even within the EU, Member States take very different approaches to sea level rise, with varying degrees of centralized competence and coordination. As a non-EU case study, the authors examine Australia, where planning is even more decentralized and where local authorities have required prompting from the courts. Thus, there is as yet no consensus on the 'federalism' issue in climate governance - that is, on what levels of government should be involved and how they should coordinate.

24 See UNFCCC, 'Climate Change: Impacts, Vulnerabilities and Adaptation in Developing Countries' (2007), available at: http://unfccc.int/resource/docs/publications/impacts.pdf (noting the particular vulnerabilities of developing countries to climate change).

25 See, e.g., V. Flatt, 'Adapting Laws for a Changing World: A Systemic Approach to Climate Change Adaptation' (2012) 64(1) Florida Law Review, pp. 269-93; H. Doremus, 'Adaptive Management as an Information Problem' (2011) 89 North Carolina Law Review, pp. 1455-95; R. Kundis Craig, "'Stationarity is Dead" - Long Live Transformation: Five Principles for Climate Change Adaptation Law' (2010) 34(1) Harvard Environmental Law Review, pp. 9-73; R.L. Glicksman, 'Climate Change Adaptation: A Collective Action Perspective on Federalism Considerations' (2010) 40(4) Environmental Law, pp. 1159-93, at 1159; A.E. Camacho, 'Adapting Governance to Climate Change: Managing Uncertainty Through a Learning Infrastructure' (2009) 59(1) Emory Law Journal, pp. 1-78, at 26-7.

26 See, e.g., K. Hasselman et al., 'The Challenge of Long-Term Climate Change' (2003) 302(5652) Science, pp. 1923-5, at 1924 (Figure 2) (predicting a two metre increase in sea level under a 'business as usual' scenario by 2100 ; but only 20 centimetres under an optimum regulatory strategy).

27 A.B. Pittock, Climate Change: Turning Up the Heat (Routledge, 2005) gives examples, including China at p. 264, India, Pakistan and Bangladesh at p. 268, and the United States at p. 278.

28 See E. Kolbert, Field Notes from a Catastrophe: Man, Nature, and Climate Change (Bloomsbury, 2006), pp. 223-4 (British governmental study indicating that what are now hundred-year floods could become routine by late in this century); see also Pittock, ibid., p. 118 (stating that, without adaptive measures, annual flood losses would increase from £1-24 billion in different scenarios).

29 J. Verschuuren \& J. McDonald, 'Towards a Legal Framework for Coastal Adaptation: Assessing the First Steps in Europe and Australia (2012) 1(2) Transnational Environmental Law, pp. 355-79. 
More generally, adaptation governance presents many unresolved issues. Peel, Godden and Keenan point out that that the 'roles and responsibilities of different levels of government and different sectors in society in relation to adaptation are not clearly defined and there is a varying understanding of the needs, priorities and mechanisms for adaptation in different parts of government, across industry sectors and within the broader community'. ${ }^{30}$ We clearly need much more thought about how current adaptation efforts are arranged and how future efforts can be organized more effectively. Transnational environmental law will be at the heart of these efforts.

\section{THE PUBLIC-PRIVATE INTERFACE}

We now turn to the way in which governance affects private arrangements regarding resource use. The legal system divides control over resources through governance rules, directives to private parties, and decisions by private parties about resource use.

Governance structures may serve intrinsic values such as public participation, but their fundamental purpose is to modify behaviour, often of private parties. In the context of environmental law, the changes involve the use of resources such as air, water and land. A web of land use regulations, property laws and contractual arrangements already govern these resources. For instance, property rules designate what actors have control over what resources, whether the resource is land, air or water. Climate governance will reshape existing patterns of control. New property rights may come into existence while old ones may be modified.

Climate governance can augment existing rights, creating the opportunity for new types of private ordering. Climate mitigation schemes create a variety of property-like instruments, which form part of a larger set of what could be called environmental property rights (EPRs). In an emissions trading system, emissions allowances permit a firm that reduces its emissions to profit by selling its allowance. ${ }^{31}$ Once the pollution permits have been allocated initially, they are transferable, and sale prices function as free-market equivalents of pollution taxes. The permits have value because emissions are subject to an overall cap.

Another common form of EPR involves offsets or mitigation credits. Greenhouse gas offsets, also commonly called carbon offsets, allow an emitter to meet the requirements of a cap-and-trade scheme by purchasing a carbon reduction by a third-party who is outside the trading system. These offsets could take the form of reduced emissions in the US or perhaps elsewhere, such as the substitution of a natural gas electricity generator for a coal-fired generator in China. Alternatively, they could involve the

30 Peel et al., n. 11 above, at p. 274.

31 For conceptual overviews, see R.W. Hahn \& G.L. Hester, 'Marketable Permits: Lessons for Theory and Practice' (1989)16 Ecology Law Quarterly, pp. 361-406. A related concept is the use of transferable fishing quotas to help maintain sustainable fish stocks. See D. Dana, 'Overcoming the Political Tragedy of the Commons: Lessons Learned from the Reauthorization of the Magnuson Act' (1997) 24 Ecology Law Quarterly, pp. 833-46; K.M. Fletcher, 'When Economics and Conservation Clash: Challenges to Economic Analysis in Fisheries Management' (2001) 31 Environmental Law Reporter, pp. 11168-73. 
creation of additional carbon sinks, such as planting trees. ${ }^{32}$ Unlike emissions allowances, greenhouse gas offsets come from sources or sinks that are not otherwise subject to regulatory requirements because they are in unregulated sectors or are outside the regulating jurisdiction.

Putting aside legal technicalities, it seems natural to connect EPRs with the concept of property. For example, it would be very natural to say that a company 'owns' carbon allowances or credits in the Kyoto Protocol's Clean Development Mechanism $(\mathrm{CDM}) .{ }^{33}$ Carbon allowances can be bought and sold in markets, which makes them seem as much like property as government bonds or financial derivatives. But whether EPRs such as carbon allowances should be considered a form of property legally may depend on the context. In particular, designers of a trading system should consider whether to elevate allowances to the status of property for constitutional purposes.

Sabina Manea's article addresses this issue in the context of EU emissions allowances. ${ }^{34}$ Controversy has arisen, for instance, in a UK case involving a mothballed plant, where the issue was whether the unused allowances could be placed into a trust. ${ }^{35}$ As Manea points out, US trading systems usually specify that emissions allowances can be modified at any time and are not considered as property interests. The advantage of this approach is that it preserves flexibility, but the disadvantage is that it may reduce confidence in the market for allowances.

In seeking to classify emissions allowances, Manea considers possible analogies with intellectual property rights, broadcast spectrum rights and milk quotas. Although this comparison is not of a nature to generate a definitive conclusion as to the status of the EU allowances, Manea's analysis does highlight overlaps and divergences between various rights regimes, which can be instructive in developing a richer understanding of emissions entitlements as property. Her contribution calls for further research into how best to define emissions entitlements.

Manea's article connects in interesting ways with the work of Rubini and Jegou on the question of whether free allowances constitute a forbidden subsidy under the WTO. One category of subsidies involves the free provision of goods or services to firms. Rubini and Jegou argue that allocation of emissions allowances could be considered as the provision of a good, since the allowances are tradable and have economic value. ${ }^{36}$ As Manea indicates, there is some basis for this argument but, when it comes to emissions allowances, economic value and tradability are complex matters.

Property rights also enter into climate governance in another way. Sea level rise will expose coastal lands as well as others to flood risks. As the article by Verschuuren and

32 See N. Richardson, International Greenhouse Gas Offsets under the Clean Air Act', Resources for the Future (RFF) Discussion Paper 10-24, 2010, available at: http://papers.ssrn.com/sol3/papers.cfm? abstract_id=1586037.

33 See http://unfccc.int/kyoto_protocol/mechanisms/clean_development_mechanism/items/2718.php.

34 S. Manea, 'Defining Emissions Entitlements in the Constitution of the EU Emissions Trading System' (2012) 1(2) Transnational Environmental Law, pp. 303-23.

35 Armstrong DLW GmbH v. Winnington Networks Ltd [2012] EWHC 10 (High Court of England and Wales).

36 Rubini \& Jegou, n. 19 above, at p. 337. 
McDonald indicates, climate adaptation often involves some efforts to restrict or even roll back development in areas at risk. Landowners are likely to challenge such restrictions as derogations from their property rights, particularly if they purchased the land prior to public awareness of the effects of sea level rise.

While those claims involve clearly established legal rights in land, climate policy may prompt calls to newly recognize certain types of ownership right. In an examination of the operation of the REDD+ mechanism in Mozambique, ${ }^{37}$ Grit Ludwig raises the question of how to protect the rights of indigenous peoples and local communities. Given incomplete titling or definition of property rights, along with political obstacles, such communities may be unable to have an effective voice in the management of the forest lands on which they depend. In Mozambique, for instance, title to land remains in the state, with private entities receiving only a usage right that can be inherited but is not transferrable. Local communities have some right to use forest resources for subsidence; in the face of commercial development, however, they are entitled only to notice of development projects, and they find it difficult to access forests for commercial use because of the onerous licensing procedures. Thus, they are poorly positioned to defend their property and participation rights.

Ludwig views this as a widespread problem for many local communities and indigenous peoples living in forests worldwide. ${ }^{38}$ In the absence of efforts to strengthen their property rights, she argues, these communities may lose control of their lands, fail to benefit from REDD, and even find themselves faced with restricted access and physical displacement. ${ }^{39}$ REDD itself may suffer from the absence of the benefits associated with community involvement in forest preservation.

The issue of community participation in REDD decisions can be viewed as one of property law, as Ludwig does. But it can also be considered as an issue of resource governance that would be important regardless of property rules. Governance rules in public law serve the same function as property rules in private law: they allocate the power to make decisions about resource use.

Property issues illustrate the ways in which climate change will affect interactions between private parties and aspects of law that are not explicitly 'environmental'. Climate is, after all, a pervasive aspect of life, and climate change is closely connected with the crucial energy, land use and food production systems. There is every reason to expect continued evolution in the legal rules governing these linked systems. That evolution will provide fruitful ground for developing transnational environmental legal analysis.

We are only a few decades into the era of overt climate change. Until we have transitioned into a zero-carbon society, we will continue to have a need to control conventional energy and land use conversion. Eventually, the governance system required to do so may shake down into a clear, organized structure. In the meantime,

\footnotetext{
37 G. Ludwig, 'Property Rights and Participation in REDD+: The Case of Mozambique' (2012) 1(2) Transnational Environmental Law, pp. 381-401.

38 Ibid., at p. 398.

39 Ibid., at p. 383.
} 
transnational climate governance will continue to involve messy vertical, horizontal, and triangular relationships. Legal scholars will find much to occupy them as they attempt to rationalize and critique this evolving transnational system. The articles in this issue make an essential contribution to this goal by mapping out some of the contours of our future governance systems. It will take many years to fill in the details.

Editors-in-Chief

Thijs Etty

Veerle Heyvaert

Editors

Cinnamon Carlarne

Dan Farber

Jolene Lin

Joanne Scott 